\title{
Walwhalleya jacobsiana (Poaceae, Paniceae), a new, rare species of grass from South Australia
}

\author{
Jeremy J. Bruhl and R.D.B. (Wal) Whalley
}

\author{
Botany and N.C.W. Beadle Herbarium, School of Environmental and Rural Science, University of \\ New England, Armidale NSW 2351 Australia \\ Author for correspondence: jbruhl@une.edu.au; rwhalley@une.edu.au
}

\begin{abstract}
Phenetic (ordination and cluster) analysis using an extensive morphometric character set of all three species of the grass genus Walwhalleya (W. pungens, W. subxerophylla and W. proluta) and the monospecific Homopholis (H. belsonii) corroborated intuitive recognition of a new species, 'Walwhalleya sp. Flinders Ranges'. The new species is characterised in part by prominently strigose upper glumes and lower lemmas. Known only from two gatherings, and likely rare, we assign it the IUCN conservation status of 'data deficient'. We name this new species Walwhalleya jacobsiana in honour of Surrey Jacobs.
\end{abstract}

\section{Introduction}

Previous phenetic and cladistic analyses of some members of Paniceae resulted in the erection of the new genus Walwhalleya (K.E.Wills \& J.J.Bruhl) K.E.Wills \& J.J.Bruhl (syn. Whalleya K.E.Wills \& J.J.Bruhl, nom. illeg. non Whalleya J.D.Rogers, Y.M.Ju \& F. San Martín). The genus includes Walwhalleya proluta (F.Muell.) K.E.Wills \& J.J.Bruhl, W. subxerophylla (Domin) K.E.Wills \& J.J.Bruhl and the newly described W. pungens (K.E.Wills \& J.J.Bruhl) K.E.Wills \& J.J.Bruhl. Homopholis C.E.Hubb., from which Walwhalleya was separated, was restricted to the type species, H. belsonii C.E.Hubb. (Webster 1987; Wills et al. 2000; Bruhl et al. 2006).

In preparing to return loans for our previous studies of these grasses (Wills et al. 2000; Bruhl et al. 2006), we examined 120 specimens of Walwhalleya proluta from MEL and 65 specimens from $\mathrm{AD}$ that had not been used in the previous analyses. Two gatherings from the Flinders Ranges appeared to be distinctly different from the rest of the specimens, and we intuitively segregated them as a putative new species. We also observed unrecorded variation in spikelet indumentum in some other specimens. The aim of the present study was to investigate the extent of morphological variation among the additional 185 specimens, and their taxonomic status. 


\section{Materials and Methods}

Selection of specimens: thirty five specimens (Table 1) were used as operational taxonomic units (OTUs) (cf. Wills et al. 2000), including additional material of Walwhalleya proluta from $\mathrm{AD}$ and MEL to sample the range of indumentum on the glumes and lower lemma, including the two morphologically distinct specimens from $\mathrm{AD}$. Selection of OTUs was biased towards presence of good vegetative and flowering material. An additional specimen each of W. pungens and Homopholis belsonii was selected to verify that the scoring of characters in the new study by RDBW was consistent with that of Wills (1996). All the original specimens examined by Wills (1996) were reassessed in this study for extra characters.

Character selection: the original data set used by Wills et al. (2000) was reduced to only include vegetative, inflorescence and spikelet morphological characters. OTUs of other genera and species such as Digitaria coenicola (F.Muell.) Hughes, Panicum effusum R.Br. and P. queenslandicum Domin, included in Wills et al. (2000), were omitted here. Attributes from the original study rendered invariant in the present data set were removed. Obvious differences apparent in the indumentum of the glumes and lemmas among the new specimens prompted the addition of further characters (see asterisks in Table 2). A total of 82 characters were used in the analyses (Table 2). Characters were scored on dried herbarium specimens or rehydrated material for some of the spikelet characters. Methods for morphology, micromorphology and anatomy follow Wills et al. (2000).

Analyses: a single data matrix was constructed for all characters (Appendix 1). Cluster and ordination analyses were undertaken using PATN V. 3.03 (Blatant Fabrications Pty. Ltd). All characters were given equal weighting in the analyses. Gower Metric was used for the association measure. Phenograms were produced using flexible UPGMA with $\beta=-0.1$. Three dimensional ordination plots of semi-strong hybrid multidimensional scaling (SSH MDS) were generated. 'Number of iterations' was increased to 1000 to minimise stress in the ordination. Phenograms, ordination scatter plots and plots of correlation of characters with ordination pattern (PCC) were produced directly from PATN and figures colour-coded using Adobe Illustrator CS3 v. 13.0. The criteria for accepting the putative species as distinct entities were 1) the OTUs representing the putative species formed a discrete group distinct from all other groups of OTUs in both cluster and ordination analyses and 2) the two OTUs within this group exhibited minimal dissimilarity compared with known species included in the analyses (see Wills et al. 2000; Plunkett et al. 2009).

Table 1. Vouchers for specimens in phenetic analyses. Species: OTU, voucher.

Homopholis belsonii: HB1, R. Tremont 4 (NE); HB2, R. Tremont 5 (NE); HB3, R. Tremont 1 (NE); $\mathrm{HB} 4, R$. Tremont 3 (NE); HB5, AD 99040158; HB6, R. Tremont 2 (NE); Walwhalleya proluta: WPR1, MEL 1620815; WPR2, MEL 1564746; WPR3, AD 98446400; WPR4, MEL 570575; WPR5, MEL 1620817; WPR6, AD 97507128; WPR7, AD 97636285; WPR10, MEL 1620816; WPR11, AD 98665088; WPR12, MEL 1511529; WPR13, N.C.W. Beadle s.n., 2 Nov. 1970 (NE 24894); WPR14, AQ 418275; WPR15, NSW 365202; WPR16, MEL 225501; WPR17, NSW 221763; WPR18, NSW 355220; Walwhalleya sp. Flinders Ranges: WPR8, AD 97021093; WPR9, AD 97215110; W. pungens: WPU1, K.E. Wills 100 (NE); WPU2, K.E. Wills 83b (NE); WPU3, K.E. Wills 108 (NE); WPU4, K.E. Wills 69b (NE); WPU5, J.R. Hosking 1622 (NE67741); WPU6, K.E. Wills 69a (NE); W. subxerophylla: WS1, AQ 425324; WS2, NSW 220377; WS3, NSW 254088; WS4, NE 8579; WS5, M. Driver s.n., Sep. 1978 (NE 40105). 


\section{Results and Discussion}

Phenetic patterns from SSH MDS ordination and UPGMA clustering (Figs 1 \& 2) are essentially the same and recover the same groups as we intuitively predicted and are consistent with those of previous analyses of the group by Wills et al. (2000). The stress value of the ordination is very low (0.0607) and most of the characters correlate strongly with the ordination space (Table 3 ).

Five distinct groupings of OTUs were obtained. One group, whose OTUs had not been previously analysed, represents the two Herbarium AD specimens from the Flinders Ranges allocated by AD to Homopholis proluta. This group appears more similar to $W$. subxerophylla than to either W. proluta or W. pungens phenetically (Figs $1 \& 2$ ) and morphologically (Fig. 3) and is here referred to as Walwhalleya sp. Flinders Ranges until formally described below. This new species is readily distinguished, with the aid of a hand lens, from other members of the genus by strigose upper glumes and lower lemmas of its spikelets (Fig. 3).

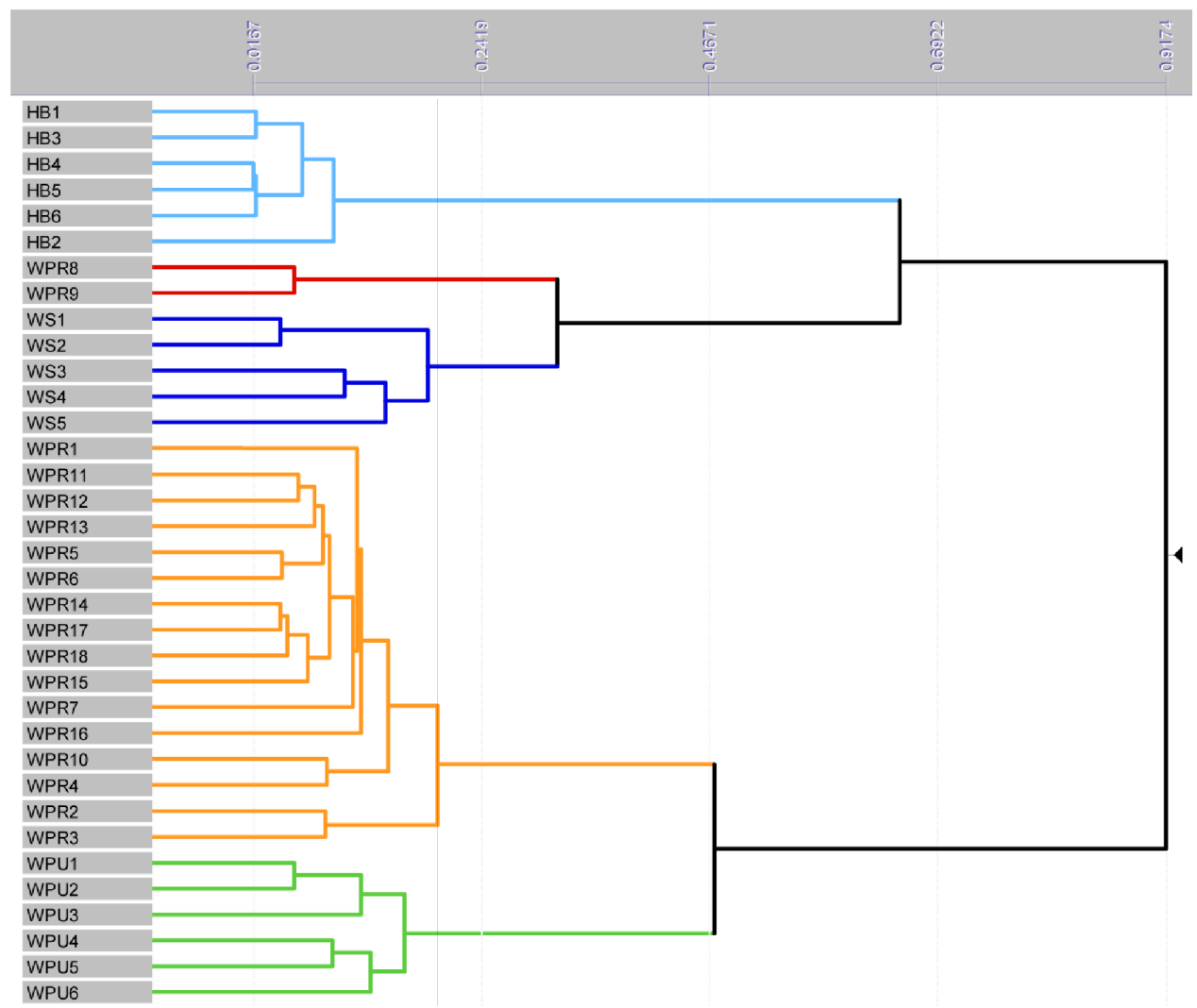

Fig. 1. Phenogram based on Gower association and flexible UPGMA with $\beta=-0.1$ of OTUs of Homopholis and Walwhalleya. $\mathrm{HB}=$ Homopholis belsonii, $\mathrm{WPR}=$ Walwhalleya proluta, WS= W. subxerophylla, WPU $=W$. pungens. Following analyses WPR8 and WPR9 were assigned to Walwhalleya sp. Flinders Ranges. See Table 1 for vouchers. 


\section{Table 2. Morphological characters used for ordination and cluster analyses of Walwhalleya and Homopholis. * $=$ Characters additional to those used in the analysis by Wills et al. (2000).}

No. Character: States

\section{Vegetative}

1. plants: stoloniferous/not stoloniferous

2. auricle: present/absent

3. ligule length $(\mathrm{mm})$

4. leaf width $(\mathrm{mm})$

5. leaf tip: pungent/not pungent

6. leaf blade adaxial surface: hairy/not hairy

\section{Inflorescence}

7. inflorescence at maturity: fully exserted/not fully exserted

8. primary inflorescence branches: spreading/not spreading

9. primary inflorescence branches degree of secondary branching: many/not many

10. primary inflorescence branches: spikelets appressed/not appressed

11. primary inflorescence branches: spikelets ascending/not ascending

12. primary inflorescence branches at lowermost inflorescence node: whorled/not whorled

13. pedicels: flexuose/not flexuose

14. spikelet: number on a typical lowermost branch

\section{Spikelet}

15. spikelet shape: lanceolate/not lanceolate

16. spikelet length $(\mathrm{mm})$

17. spikelet width $(\mathrm{mm})$

18. spikelet length to width ratio

19. lower glume length $(\mathrm{mm})$

20. lower glume shape: triangular/not triangular

21. lower glume shape: ovate/not ovate

22. lower glume shape: lanceolate/not lanceolate

23. lower glume shape: elliptic/not elliptic

24. lower glume number of nerves

25. lower glume texture: rough/not rough

26. lower glume apex shape: long acuminate/not long acuminate

27. lower glume apex shape: acuminate/not acuminate

28. lower glume apex shape: acute/not acute

29. lower glume apex shape: rounded/not rounded

30. *lower glume intercostal indumentum in the upper third: present/not present

31. *lower glume intercostal indumentum in the lower two thirds: present/not present

32. * *ower glume vein indumentum scabrous/not scabrous

33. * *ower glume mid vein indumentum in upper third: present/not present

34. *lower glume mid vein indumentum in lower two thirds: present/not present

35. *lower glume lateral vein indumentum in upper third: present/not present

36. * $\quad$ lower glume lateral vein indumentum in lower two thirds: present/not present

37. lower glume ratio to spikelet length

38. upper glume length $(\mathrm{mm})$ 
39. upper glume number of nerves

40. upper glume texture: membranous/not membranous

41. upper glume texture: chartaceous/not chartaceous

42. upper glume: hairy/not hairy

43. *upper glume intercostal indumentum type: scabrous/not scabrous

44. *upper glume intercostal indumentum: strigose/not strigose

45. *upper glume intercostal indumentum in upper third: present/not present

46. *upper glume intercostal indumentum in lower two thirds: present/not present

47. *upper glume vein indumentum: scabrous/not scabrous

48. *upper glume vein indumentum: strigose/not strigose

49. *upper glume mid vein indumentum in upper third: presents/not present

50. *upper glume mid vein indumentum in lower two thirds: present/not present

51. *upper glume lateral vein indumentum in upper third: present/not present

52. *upper glume lateral vein indumentum in lower two thirds: present/not present

53. lower lemma texture: membranous/not membranous

54. lower lemma texture: chartaceous/not chartaceous

55. lower lemma apex shape: long acuminate/not long acuminate

56. lower lemma apex shape: acuminate/not acuminate

57. lower lemma apex shape: acute/not acute

58. lower lemma nerves: producing slit-like interspaces/not producing slit-like interspaces

59. * *ower lemma intercostal indumentum type: scabrous/not scabrous

60. * *ower lemma intercostal indumentum type: strigose/not strigose

61. *lower lemma intercostal indumentum in upper third: present/not present

62. *lower lemma intercostal indumentum in lower two thirds: present/not present

63. * *ower lemma vein indumentum: scabrous/not scabrous

64. *lower lemma vein indumentum: strigose/not strigose

65. *lower lemma mid vein indumentum in upper third: present/not present

66. *lower lemma mid vein indumentum in lower two thirds: present/not present

67. *lower lemma lateral vein indumentum in upper third: present/not present

68. *lower lemma lateral vein indumentum in lower two thirds: present/not present

69. lower lemma number of nerves

70. upper lemma colour at maturity: brown/not brown

71. upper lemma texture: cartilaginous/not cartilaginous

72. upper lemma texture: indurate/not indurate

73. upper lemma surface ornamentation: smooth/not smooth

74. upper lemma surface ornamentation: minutely muricate/not minutely muricate

75. upper lemma surface ornamentation distribution: regular/not regular

76. upper lemma margins recurved: thinner than body/not thinner than body

77. upper lemma apex: shortly beaked/not shortly beaked

78. upper lemma with a membranous point: yes/no

79. upper floret shorter than lower floret: yes/no

80. upper lemma length $(\mathrm{mm})$

81. upper palea with a prominent keel: yes/no

82. lodicule length $(\mu \mathrm{m})$ 
Here, W. proluta and W. pungens are more similar to each other than to other members of Walwhalleya and Homopholis, whereas Wills et al. (2000) found W. pungens and W. subxerophylla to be more similar. Also, in the present study $H$. belsonii appears more similar to $W$. subxerophylla and W. sp. Flinders Ranges than to W. proluta and $W$. pungens by contrast to Wills et al. (2000). Based on exploratory analyses where we have removed some OTUs/characters (not presented), the differences between our present and previous findings largely result from the inclusion here of Walwhalleya sp. Flinders Ranges and the expanded use of characters capturing features of the indumentum on the glumes and lemmas. Lower stress values obtained here, despite an increase in number of attributes, lends confidence to our main findings.

Nevertheless, neither pattern of similarity is unreasonable based on current knowledge of the geographic distributions of the species of Walwhalleya (see Australia's Virtual Herbarium, www.ersa.edu.au/avh/), and we do not interpret these phenetic results as an estimation of phylogeny. Rather, we will collaborate with others on molecular phylogenetics to test and extend the earlier (Wills et al 2000) non-molecular phylogeny of the group. New collections of Walwhalleya sp. Flinders Ranges will be useful towards this purpose and in the better assessment of its rarity. So, we encourage a search for this new and rare member of the South Australian flora.

\section{Conclusions}

There is clear evidence from morphology and phenetic analysis confirming intuitive assessment of the recognition of a fourth species of Walwhalleya: W. sp. Flinders Ranges, which we formally name below. Given the widespread and thorough wetting

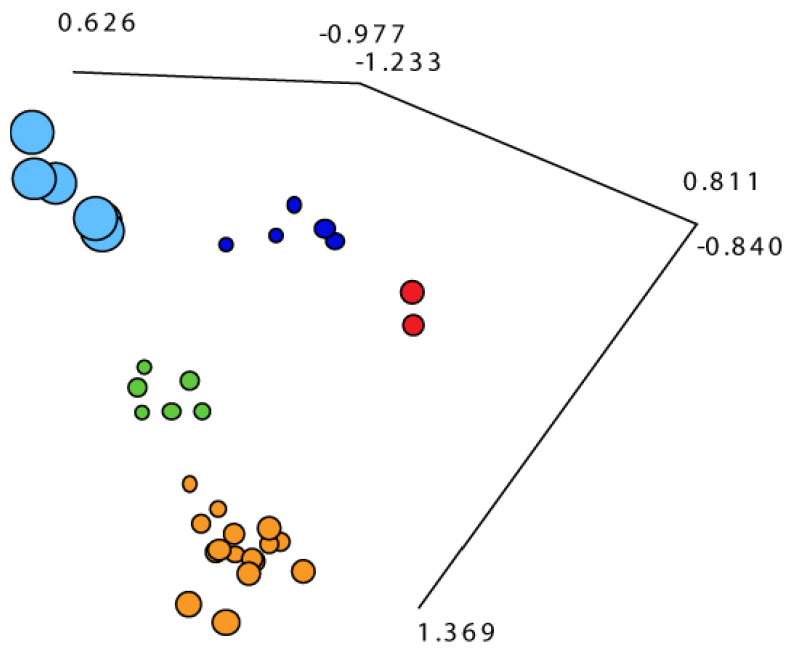

Fig. 2. 3D-ordination of semi-strong hybrid multidimensional scaling for OTUs of Homopholis and Walwhalleya. Stress $=0.0607$. From top left hand, clockwise: Homopholis belsonii, Walwhalleya subxerophylla, Walwhalleya sp. Flinders Ranges, W. proluta, W. pungens. 

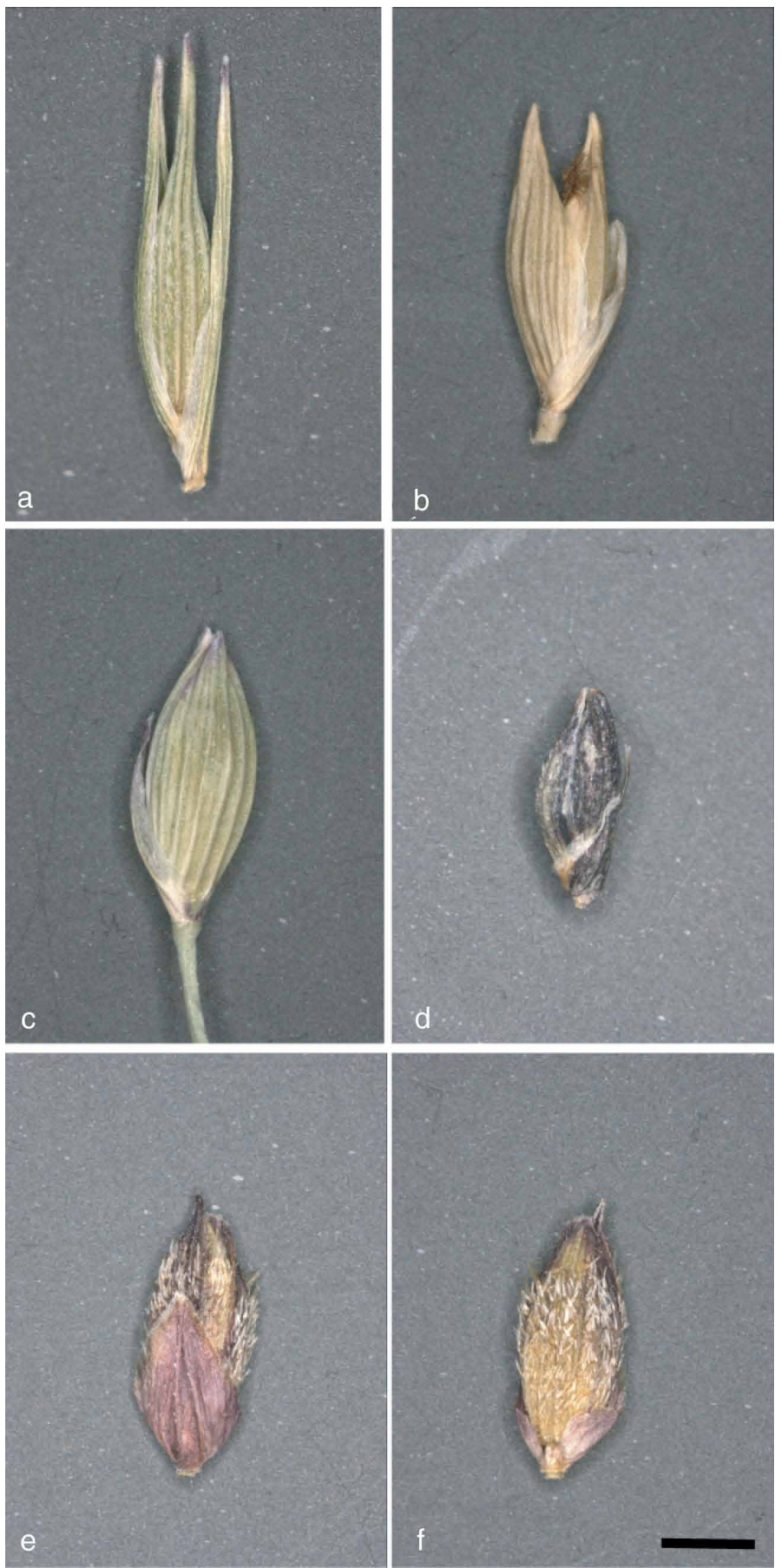

Fig. 3. Spikelets of the study group species. a, Homopholis belsonii (R.Tremont 3, NE); b, Walwhalleya proluta (AD 97507128); c, W. pungens (K.E.Wills 69b, NE); d, W. subxerophylla (NE 8579); e, f, $W$. sp. Flinders Ranges (AD 97215110). Scale bar: a-f $=1 \mathrm{~mm}$. 
Table 3. PCC values with correlation of attributes with ordination space of $70 \%$ or more, for SSH MDS ordination of Walwhalleya and Homopholis; see Fig. 2. * = characters additional to those used in the analysis by Wills et al. (2000); see Table 1.

\section{No. Character}

23 lower glume shape: elliptic/not elliptic

44 *upper glume intercostal indumentum: strigose/not strigose

67 *lower lemma lateral vein indumentum in upper third: present/not present

63 *lower lemma vein indumentum: scabrous/not scabrous

$65 *$ lower lemma mid vein indumentum in upper third: present/not present

6 leaf blade adaxial surface: hairy/not hairy

15 spikelet shape: lanceolate/not lanceolate

22 lower glume shape: lanceolate/not lanceolate

26 lower glume apex shape: long acuminate/not long acuminate

55 lower lemma apex shape: long acuminate/not long acuminate

75 upper lemma surface ornamentation distribution: regular/not regular

60 *lower lemma intercostal indumentum type: strigose/ not strigose

56 lower lemma apex shape: acuminate/not acuminate

9 primary inflorescence branches degree of secondary branching: many/not

47 *upper glume vein indumentum: scabrous/ not scabrous

49 *upper glume mid vein indumentum in upper third: presents/not present

51 *upper glume lateral vein indumentum in upper third: present/not present

5 leaf tip: pungent/not pungent

19 lower glume length $(\mathrm{mm})$

46 *upper glume intercostal indumentum in lower two thirds: present/not present

45 *upper glume intercostal indumentum in upper third: 0.608 present/not present

24 lower glume number of nerves

38 upper glume length $(\mathrm{mm})$ present/not present

74 upper lemma surface ornamentation: minutely muricate/-0.015 not minutely muricate

16 spikelet length $(\mathrm{mm})$
$-0.054$

$-0.227$

0.579

$\begin{array}{lll}X & Y & Z\end{array}$

r-squared

$-0.776$

0.63

0.007

0.92

0.776

$-0.63$

$-0.007$

0.92

0.776

$-0.63$

$-0.007$

0.92

$\begin{array}{ll}-0.534 & 0.093\end{array}$

0.88

$\begin{array}{ll}-0.534 & 0.093\end{array}$

0.88

$-0.075$

$0.928-0.365$

0.85

0.075

$-0.928$

0.365

0.85

0.075

$-0.928$

0.365

0.85

0.075

$-0.928$

0.365

0.85

0.075

$-0.928 \quad 0.365$

0.85

$-0.075$

$0.928-0.365$

0.85

0.708

$-0.671$

0.219

0.84

$-0.747$

0.64

$-0.18$

0.80

$-0.981$

0.039

$-0.192$

0.80

0.98

$-0.199-0.013$

0.80

0.98

$-0.199 \quad-0.013$

0.80

$-0.199 \quad-0.013$

0.80

$-0.755$

0.637

$-0.157$

0.78

$-0.725$

0.684

0.75

$\begin{array}{ll}-0.014 & 0.067\end{array}$

0.75

$0.792 \quad-0.061$

0.73

$-0.69$

0.722

0.72

$-0.718$

0.658

0.71

0.805

$-0.129$

0.69

$\begin{array}{lll}0.959 & -0.283 & 0.69\end{array}$

$-0.691 \quad 0.696$

0.69 
of much of inland Australia in 2010 and the consequent fabulous growth of grasses and other herbs, we encourage collection of high quality specimens (and data) of grasses from these areas to aid the assessment of their distribution and to maximise the chance of discovery of new species of Poaceae.

\section{Taxonomy}

Walwhalleya jacobsiana R.D.B.Whalley \& J.J.Bruhl, sp. nov.

W. subxerophila (Domin) K.E.Wills \& J.J.Bruhl affinis, sed gluma supera et lemmate infero strigosa inter nervos differt.

Type: South Australia. Flinders Range[s], north, Oraparinna National Park, Hans Heysen Range. c. 18 km west-north-west of Oraparinna homestead. 17 Sep. 1971, E.N.S. Jackson 1880; holo: AD; iso: BRI, CANB, K, MEL, MO, NE, NSW, PERTH, PRE, SI, US. Fig. 4.

Plants hermaphrodite; perennial; non-rhizomatous; cataphylls absent. Flowering culms erect; clumped; $10-20 \mathrm{~cm}$ tall; mostly sparingly branched; inflorescences terminal, solitary; 4-8 noded. Flowering culm nodes glabrous. Mid-culm internodes hollow; glabrous; shorter than the associated leaf sheaths. Auricles absent. Mid-culm leaves not distinctly distichous. Mid-culm sheaths rounded at the back; glabrous; sheath margins non-ciliate; sheath nerves smooth. Ligule a membrane; $1.5-2.8 \mathrm{~mm}$ long; erose, or entire; apically rounded to truncate. Collar glabrous. Mid-culm leaf blades involute; 4-10 × 1.6-2.5 mm; linear; adaxially hairy, scabrous; not noticeably thickened and spongy; tapering to a narrow apex (sharp, spine-like); non-ciliate basally; with scabrous margins; without tubercle-based hairs.

Inflorescence a panicle usually fully exserted at maturity (apparent in R.Callen s.n. 8 Oct. 1969, AD). Main inflorescence axis present; 40-80 mm long; scabrous. Primary inflorescence branches initially appressed, spreading with maturity; whorled at the lowermost inflorescence node; with few secondary branches; axils hairy; (15-)30-50 $\times 0.2-0.5 \mathrm{~mm}$; distinctly grooved or angled; not winged; smooth on the faces; lacking papilla-based setae; scabrous on the angles. Spikelet-bearing branches not basally adnate to the rachis; terminating in a spikelet. Spikelets initially appressed to the branches, later ascending; arranged singly on the branches; not secund. Bristles absent. Pedicels present; 15-50 mm long; distinctly angled; scabrous; flexuose or straight. Pedicel apices glabrous; concave, cupuliform. Disarticulation at the base of the spikelet. Callus not differentiated. Spikelets not overlapping; solitary; $1-3$ on a typical lowermost branch; not embedded in the rachis; not diverging from the axis.

Spikelets dorsiventrally compressed; ellipsoid; $2.5-2.9 \times 1.1-1.3 \mathrm{~mm}$. First glume present; $1.7-2.1 \mathrm{~mm}$ long (c. $0.6-0.7 \times$ spikelet length); ovate; encircling the spikelet base; not inflated at the base; 5-7-nerved; membranous; veins scabrous in the upper third; acute to acuminate; rachilla pronounced between the first and second glume. Second glume 2.2-2.6 mm long; elliptic; 7-9-nerved; rounded on the back; chartaceous; margins neither noticeably flared nor hyaline, non-ciliate; with both intercostal and vein indumentum, intercostae strigose, vein indumentum both scabrous and strigose; acute, muticous; c. $1 \times$ the length of the lower lemma. Lower floret neuter. Lower lemma elliptic; lacking distinct transverse nerves; not keeled; chartaceous; lacking a hyaline area at the base; internerve spaces equal; 7-9-nerved, nerves not anastomosing apically, without slit-like interspacing, pronounced; margins non-ciliate, thin; intercostal indumentum 


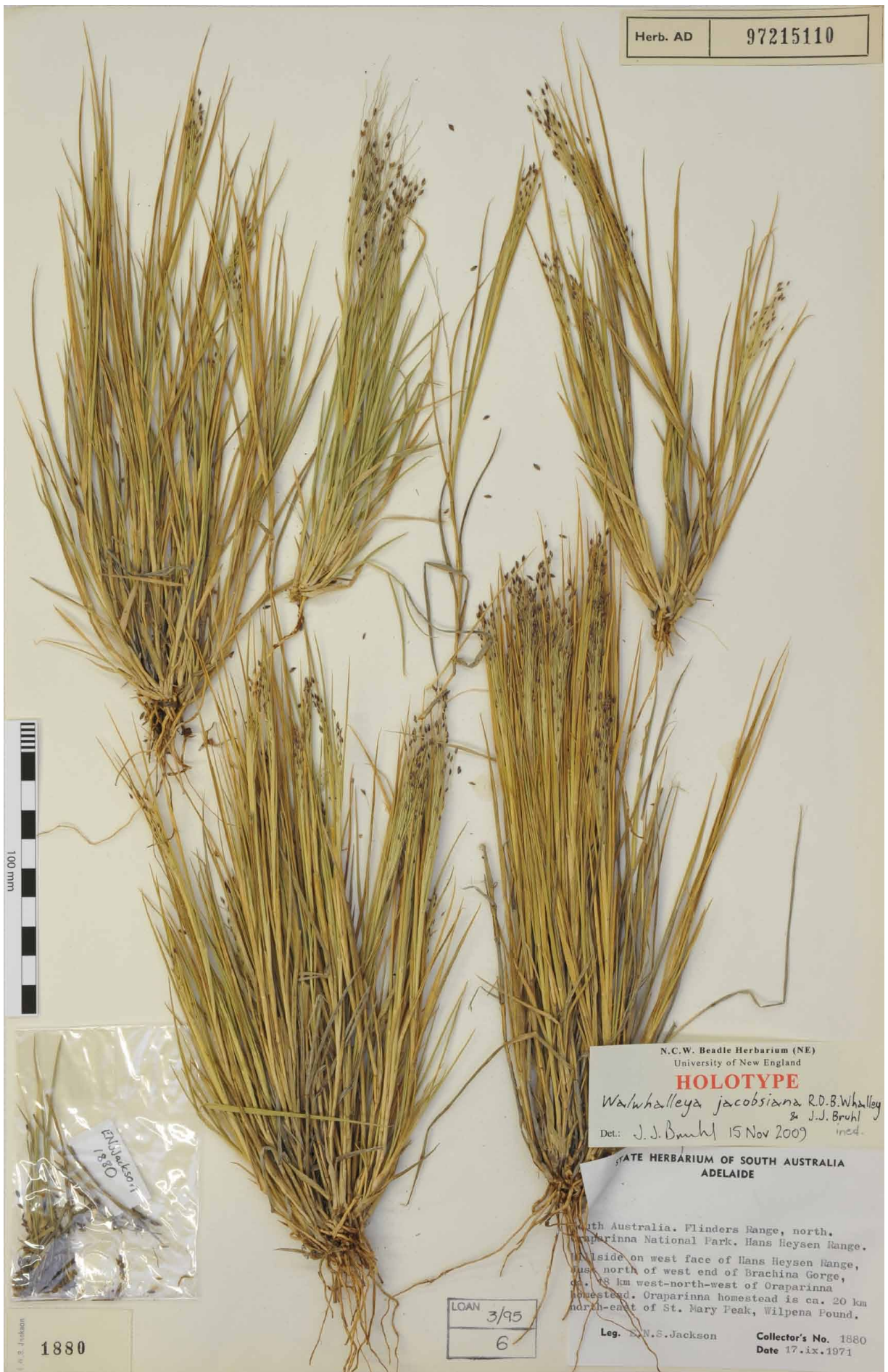

Fig. 4. Image of holotype of Walwhalleya jacobsiana (AD 97215110). Inflorescences at various stages towards maturity. 
strigose, vein indumentum both scabrous and strigose; acute, muticous. Palea of lower floret absent or minute. Rachilla not well developed between the lower and upper floret. Upper floret perfect; shorter than the lower floret. Upper lemma 1.7-2.1 mm long; indurate; very finely muricate; elliptic; rounded on the back; obscurely nerved; margins recurved and not noticeably thinner than the body (at maturity); glabrous; base without special modifications; the apex not differentiated into a membranous green point; lacking an apical crest; recurved apically; acuminate; apiculate. Palea of upper floret indurate; very finely muricate; with the base neither swollen nor protruding; with obscure nerves; enclosed at its apex by the lemma. Lodicules well developed; plicate; $8.5-11 \mu \mathrm{m}$ long. Anthers 3. Styles basally free. Rachilla not prolonged beyond the upper floret. Differentiated cleistogamous spikelets absent.

Abaxial epidermis of leaf blade: costal/intercostal zonation conspicuous; veins scabrid. Epidermis with differentiated long and short cells. Long cells similar in shape and wall thickness costally and intercostally. Microhairs present, $25-50$ x $5-8.8 \mu \mathrm{m}$ at the septum; confined to the non-stomatal files; adjacent to the costal zone and in the middle of the costal zone; panicoid-type; elongated; clearly two-celled; inflated and rounded; having both cells more or less the same shape. Distal cells blunt. Basal cell base neither constricted nor expanded; parallel-sided. Microhair apical cells 12.5-27.5 $\mu \mathrm{m}$ long. Microhair ratio of apical cell to total length $0.3-0.62$. Microhair ratio of width at septum to total length $0.14-0.3$. Stomata common; 30.0-32.5 $\mu \mathrm{m}$ long.

Photosynthetic pathway: $\mathrm{C}_{3}$ inferred from a 'maximum cells distant count' of $>1$ (see Hattersley and Watson 1975)

Distribution and habitat: known only from the Flinders Ranges: Heysen Range of Flinders Ranges National Park, Oraparinna Section and Gammon Range of Vulkathunha-Gammon Ranges National Park. No direct habitat information is available, but the species grows in a semi-arid region and is recorded from a hillside making it likely that it occurs in open woodlands and/or herbfields.

Only other specimen known: South Australia: northern Flinders Range[s], north side of Gammon Range, R. Callen s.n., 8 Oct. 1969 (AD97021093).

Phenology: flowers: Sep-Oct; fruits: Sep-Oct.

Conservation status: Walwhalleya jacobsiana is known only from two gatherings, one each from Heysen Range and Gammon Ranges in the Flinders Ranges, separated by c. $50 \mathrm{~km}$. Given the lack of data, the species should be considered 'data deficient' (DD) according to IUCN 2001 criteria (www.iucnredlist.org/technical-documents/ categories-and-criteria/2001-categories-criteria), which is also used by South Australia's Department of Environment and Heritage to assess rare and threatened species (National Parks and Wildlife Council 2003). Nevertheless, based on number of collections in this reasonably well botanised area, the species is likely rare. Priority should be given to refind the species and commence assessment of its conservation status. Good rains in 2010 provide a timely opportunity to commence this search. The species is conserved in Flinders Ranges National Park, Oraparinna Section and Vulkathunha-Gammon Ranges National Park.

Etymology: we have named this species in honour of Herbarium NSW agrostologist Surrey Jacobs, who has been over decades an inspiration to workers in native grasses, and a friend and colleague of us both. 


\section{Key to Species of Walwhalleya}

1 Spikelets $<2.9 \mathrm{~mm}$ long; lower lemma scabrous or strigose between nerves; fertile lemma subequal to lower lemma

$1^{\star}$ Spikelets $\geq 3 \mathrm{~mm}$ long; lower lemma glabrous between nerves; fertile lemma shorter than

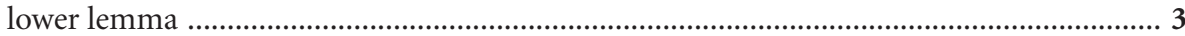

2 Upper glume and lower lemma with strigose hairs between nerves, lower lemma nerves without spicules W. jacobsiana

$2 *$ Upper glume and lower lemma without strigose hairs between nerves, lower lemma nerves with spicules W. subxerophila

3 Mid-culm leaf blades flat; upper glume glabrous, acuminate W. proluta

$3^{\star}$ Mid-culm leaf blades involute; upper glume scabrous, acute W. pungens

\section{Acknowledgments}

We thank Ian Telford (NE) and Frances Quinn (UNE) for helpful comments on a draft of the manuscript; Lyn Craven (CANB) for Latin translation; Nigel Andrew (UNE) for use of Leica MZ16A; Herbaria AD and MEL for extended loans and permission to sample specimens; Jürgen Kellermann and Helen Vonow (AD) for a copy of the SA Discussion paper and useful feedback; NSW for previous loans of relevant material and access to specimens at NSW; specimen data was accessed from Australia's Virtual Herbarium with permission of the Council of Heads of Australasian Herbaria Inc.; and referees and editorial committee for their helpful comments. We acknowledge use of the N.C.W. Beadle Herbarium (NE) and research facilities within the School of Environmental \& Rural Science, UNE.

\section{References}

Bruhl JJ, Wilson PG \& Wills KE (2006) Grass not fungus: Walwhalleya nom. nov. (Poaceae, Paniceae). Australian Systematic Botany 19: 327-328.

Hattersley PW, Watson L (1975) Anatomical parameters for predicting photosynthetic pathways of grass leaves: The 'maximum lateral cell count' and the 'maximum cells distance count'. Phytomorphology 25: 325-333.

National Parks and Wildlife Council (2003) Review of the status of threatened species in South Australia: Proposed schedules under the South Australian National Parks and Wildlife Act 1972: Discussion Paper. (Dept for Environment \& Heritage, S.A.: Adelaide) [Sept. 2003].

Plunkett GT, Bruhl JJ, Telford IRH (2009) Two new, sympatric species of Wahlenbergia (Campanulaceae) from the New England Tableland escarpment, New South Wales, Australia. Australian Systematic Botany 22: 319-331.

Webster RD (1987) The Australian Paniceae (Poaceae). (J. Kramer: Berlin)

Wills KE (1996) Systematic studies in Homopholis (Poaceae: Panicoideae: Paniceae). Graduate Diploma in Science Thesis, Botany, University of New England Armidale, NSW.

Wills KE, Whalley RDB \& Bruhl JJ (2000) Systematic studies in Paniceae (Poaceae): Homopholis and Whalleya gen. et. sp. nov. Australian Systematic Botany 13: 437-468. 


\section{Appendix 1.}

Data set for phenetic analysis of Homopholis and Walwhalleya. See Table 1 for characters relating to the numbers in header row. Empty cells are missing data. See table 1 for vouchers.

\begin{tabular}{|c|c|c|c|c|c|c|c|c|c|c|c|c|c|c|c|c|c|c|c|}
\hline TU & 1 & 2 & 3 & 4 & 5 & 6 & 7 & 8 & 9 & 10 & 11 & 12 & 13 & 14 & 15 & 16 & 17 & 18 & 19 \\
\hline HB1 & 1 & & 1.4 & 2.7 & 0 & 0 & 0.5 & 1 & 0 & 0 & 1 & 0 & 0 & 2.5 & 1 & 5.2 & 0.9 & 5.7 & 4.9 \\
\hline AB2 & 1 & 0 & 1.4 & 2.2 & 0 & 0 & 1 & 0 & 0 & & & 0 & 0 & 1.5 & 1 & 5.5 & 0.9 & 6.2 & 5.4 \\
\hline HB3 & 1 & 0 & 1.3 & 2.3 & 0 & 0 & 0.5 & 1 & 0 & 0 & 1 & 0 & 0 & 2.7 & 1 & 4.9 & 1.0 & 5.1 & 4.7 \\
\hline HB4 & 1 & 0 & 1.1 & 2.2 & 0 & 0 & 0.5 & 1 & 0 & 0 & 1 & 0 & 0 & 1.3 & 1 & 4.6 & 0.9 & 5.3 & 4.5 \\
\hline HB5 & 1 & 0 & 2.0 & 2.8 & 0 & 0 & 0.5 & 1 & 0 & 0 & 1 & 0 & 0 & 2.0 & 1 & 5.1 & 1.1 & 4.6 & 4.8 \\
\hline HB6 & 1 & 0 & 1.3 & 2.0 & 0 & 0 & 1 & 1 & 0 & 0 & 1 & 0 & 0 & 2.0 & 1 & 5.7 & 1.0 & 5.7 & 5.7 \\
\hline WPR1 & 0 & 0 & 2.5 & 2.7 & 1 & 1 & 0 & 0 & 1 & 1 & 1 & & 0.5 & 7.6 & 0 & 3.3 & 1.1 & 2.9 & 2.5 \\
\hline WPR10 & 0 & 0 & 2.6 & 4.0 & 1 & 1 & 0 & 0 & 1 & 1 & 1 & 0 & 0.5 & 15.0 & 0 & 3.7 & 1.3 & 2.8 & 3 \\
\hline WPR11 & 0 & 0 & 3.0 & 3.3 & 1 & 1 & 0 & 1 & 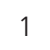 & 1 & 1 & 0 & 0.5 & 5.8 & 0 & 3.5 & 1.3 & 2.7 & 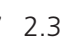 \\
\hline WPR12 & 0 & 0 & 2.3 & 4.1 & 1 & 1 & 0.5 & 1 & 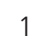 & 0 & 1 & & 0.5 & 15.3 & 0 & 3.4 & 1.1 & 3.0 & ) \\
\hline WPR13 & 0 & 0 & 1.7 & 3.6 & 1 & 1 & 0 & 1 & 1 & 0 & 1 & 0 & 0.5 & 6.0 & 0 & 3.0 & 1.1 & 2.8 & 3 \\
\hline WPR14 & 0 & 0 & 2.8 & 4.1 & 1 & 1 & 0 & 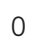 & 1 & 0 & 1 & 0 & 0.5 & 17.0 & 0 & 3.2 & 1.2 & 2.7 & \\
\hline WPR15 & 0 & 0 & 2.4 & 3.1 & 1 & 1 & 0.5 & 1 & 1 & 0 & 1 & 0 & 0.5 & 11.8 & 0 & 2.3 & 0.8 & 2.7 & 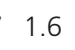 \\
\hline WPR16 & 0 & 0 & 2.6 & 5.2 & 1 & 1 & 0 & 0 & 1 & 0 & 1 & 0 & 0.5 & 18.0 & 0 & 3.5 & 1.1 & 3.2 & \\
\hline WPR17 & 0 & 0 & 2.5 & 4.2 & 1 & 1 & 0 & 0 & 1 & 0 & 1 & 0 & 0.5 & 63.0 & 0 & 3.2 & 1.0 & 3.2 & \\
\hline WPR18 & 0 & 0 & 2.3 & 3.9 & 1 & 1 & 0.5 & 1 & 1 & 0 & 1 & 0 & 0.5 & 16.5 & 0 & 3.5 & 1.1 & 3.1 & 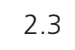 \\
\hline WPR2 & 0 & 0 & 2.0 & 4.1 & 1 & 1 & 0 & 1 & 1 & 1 & 1 & 0 & 0.5 & 15.2 & 0 & 3.4 & 1.1 & 3.0 & ) \\
\hline WPR3 & 0 & 0 & 3.2 & 3.0 & 1 & 1 & 0.5 & 1 & 1 & 1 & 1 & 0 & 0.5 & 4.4 & 0 & 3.2 & 1.2 & 2.7 & 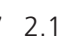 \\
\hline WPR4 & 0 & 0 & 4.0 & 3.8 & 1 & 1 & 0.5 & 1 & 1 & 1 & 1 & & 0.5 & 12.3 & 0 & 3.9 & 1.3 & 3.3 & 3.4 \\
\hline WPR5 & 0 & 0 & 2.5 & 3.0 & 1 & 1 & 0.5 & 1 & 1 & 1 & 1 & 0 & 0.5 & 8.0 & 0 & 3.5 & 1.1 & 3.2 & 2.9 \\
\hline WPR6 & 0 & 0 & 2.3 & 3.1 & 1 & 1 & 1 & 1 & 1 & 1 & 1 & 0 & 0.5 & 7.0 & 0 & 3.5 & 1.2 & 2.8 & 2.5 \\
\hline WPR7 & 0 & 0 & 4.1 & 3.0 & 1 & 1 & 0 & 1 & 1 & 0 & 1 & & 0.5 & 6.6 & 0 & 3.4 & 1.1 & 3.1 & 2.7 \\
\hline WPR8 & 0 & 0 & 2.7 & 2.2 & 1 & 1 & 1 & 1 & 0 & 0 & 1 & 1 & 0.5 & 2.4 & 0 & 2.7 & 1.3 & 2.1 & 1.7 \\
\hline WPR9 & 0 & 0 & 1.6 & 1.8 & 1 & 1 & 0 & 0 & 0 & 1 & 0 & 0 & 0.5 & 3.3 & 0 & 2.9 & 1.2 & 2.5 & ; \\
\hline WPU1 & 1 & 0 & 1.2 & 2.6 & 1 & 1 & 0.5 & 1 & 0 & 0 & 1 & 0 & 1 & 2.4 & 0 & 3.5 & 1.6 & 2.3 & 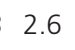 \\
\hline WPU2 & 1 & 0 & 1 & 2.2 & 1 & 1 & 1 & 1 & 0 & 0 & 1 & 0 & 0.5 & 1.0 & 0 & 3.2 & 1.4 & 2.3 & \\
\hline WPU3 & 0 & 0 & 1.4 & 2.4 & 1 & 1 & 1 & 1 & 0 & 0 & 1 & 0 & 0.5 & 2.2 & 0 & 3.3 & 1.4 & 2.4 & \\
\hline WPU4 & & 0 & 1.5 & 2.5 & 1 & 1 & 0 & 0 & 0 & 0 & 1 & 0 & 0.5 & 1.3 & 0 & 3.3 & 1.4 & 2.4 & \\
\hline WPU5 & 0 & 0 & 1.8 & 1.9 & 1 & 1 & 0 & 1 & 0 & 0 & 1 & 0 & 0.5 & 2.4 & 0 & 3.3 & 1.4 & 2.4 & 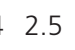 \\
\hline WPU6 & 1 & 1 & 1.4 & 2.4 & 1 & 1 & & 0 & 0 & 0 & 1 & 0 & 0.5 & 3.0 & 0 & 3.4 & 1.2 & 2.8 & 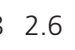 \\
\hline WS1 & 0 & 0 & 1.1 & 3.0 & 0 & 1 & 0.5 & 1 & 0 & 1 & 0 & 1 & 0.5 & 4.6 & 0 & 2.1 & 1.0 & & 1.6 \\
\hline WS2 & 0 & 0 & 2.8 & 3.8 & 0 & 1 & 0 & U & 0 & 1 & 0 & 1 & 1 & 8.2 & 0 & 2.5 & 1.1 & 2.4 & . \\
\hline WS3 & 0 & 0 & 1.9 & 2.2 & 0 & 1 & 0 & 0 & 0 & 1 & 0 & 1 & 1 & 7.0 & 0 & 2.6 & 1.0 & 2.5 & ; \\
\hline VS4 & 0 & 1 & 1.8 & 2.2 & 0 & 1 & 0.5 & 0 & 0 & 1 & 1 & 0.5 & 0.5 & 25.0 & 0 & 2.3 & 1.1 & 2.2 & 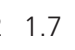 \\
\hline S55 & 0 & 1 & 2.1 & 2.0 & $c$ & 1 & 0.5 & 0 & 0 & 1 & 1 & 0.5 & 0.5 & 4.5 & 0 & 2.4 & 1.1 & 2.3 & .9 \\
\hline
\end{tabular}


$\begin{array}{llllllllllllllllllllll}\text { OTU } & 20 & 21 & 22 & 23 & 24 & 25 & 26 & 27 & 28 & 29 & 30 & 31 & 32 & 33 & 34 & 35 & 36 & 37 & 38 & 39 & 40\end{array}$ $\begin{array}{llllllllllllllllllllll}\text { HB1 } & 0 & 0 & 1 & 0 & 7 & 0 & 1 & 0 & 0 & 0 & 1 & 1 & 1 & 1 & 1 & 1 & 1 & 0.95 & 5.1 & 7 & 1\end{array}$ $\begin{array}{llllllllllllllllllllll}\text { HB2 } & 0 & 0 & 1 & 0 & 7 & 0 & 1 & 0 & 0 & 0 & 1 & 1 & 1 & 1 & 1 & 1 & 1 & 1.00 & 4.8 & 7 & 1\end{array}$ НВ3 $00 \begin{array}{llllllllllllllllllll}\text { HВ } & 1 & 0 & 7 & 0 & 1 & 0 & 0 & 0 & 1 & 1 & 1 & 1 & 1 & 1 & 1 & 0.95 & 4.7 & 7 & 1\end{array}$ $\begin{array}{llllllllllllllllllllll}\text { HB4 } & 0 & 0 & 1 & 0 & 7 & 0 & 1 & 0 & 0 & 0 & 1 & 1 & 1 & 1 & 1 & 1 & 1 & 0.98 & 4.5 & 7 & 0\end{array}$

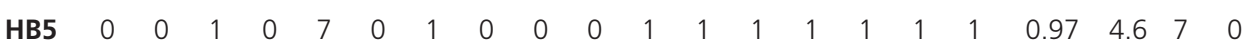

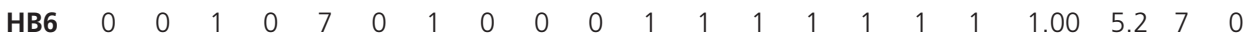
$\begin{array}{llllllllllllllllllllll}\text { WPR1 } & 0 & 0 & 0 & 1 & 5 & 0 & 0 & 0 & 1 & 1 & 1 & 1 & 0 & 0 & 0 & 0 & 0 & 0.76 & 3.0 & 9 & 0\end{array}$ $\begin{array}{lllllllllllllllllllll}\text { WPR10 } 0 & 0 & 0 & 1 & 5 & 0 & 0 & 1 & 0 & 0 & 0 & 0 & 1 & 1 & 0 & 0 & 0 & 0.83 & 3.4 & 9 & 0\end{array}$ $\begin{array}{lllllllllllllllllllll}\text { WPR110 } & 0 & 0 & 1 & 5 & 0 & 0 & 0 & 0 & 1 & 1 & 0 & 1 & 1 & 0 & 1 & 0 & 0.68 & 3.1 & 9 & 0\end{array}$ $\begin{array}{lllllllllllllllllllll}\text { WPR120 } & 0 & 0 & 1 & 5 & 0 & 0 & 0 & 1 & 1 & 1 & 0 & 1 & 1 & 0 & 1 & 0 & 0.68 & 3.3 & 7 & 0\end{array}$

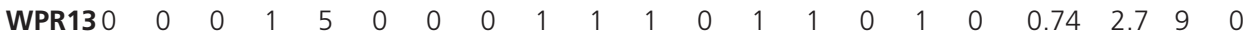
$\begin{array}{lllllllllllllllllllll}\text { WPR140 } & 0 & 0 & 1 & 5 & 0 & 0 & 0 & 1 & 1 & 0 & 0 & 1 & 1 & 0 & 0 & 0 & 0.74 & 3.2 & 9 & 0\end{array}$ $\begin{array}{lllllllllllllllllllll}\text { WPR150 } & 0 & 0 & 1 & 5 & 0 & 0 & 0 & 1 & 1 & 0 & 0 & 1 & 1 & 1 & 1 & 1 & 0.72 & 3.4 & 9 & 0\end{array}$ $\begin{array}{lllllllllllllllllllll}\text { WPR16 } 0 & 0 & 0 & 1 & 4.8 & 0 & 0 & 0 & 1 & 1 & 1 & 0 & 1 & 1 & 0 & 1 & 0 & 0.79 & 3.5 & 9 & 0\end{array}$ $\begin{array}{lllllllllllllllllllll}\text { WPR17 } 0 & 0 & 0 & 1 & 5 & 0 & 0 & 0 & 1 & 1 & 0 & 0 & 1 & 1 & 0 & 1 & 0 & 0.65 & 3.2 & 9 & 0\end{array}$

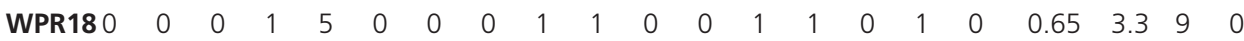
$\begin{array}{llllllllllllllllllllll}\text { WPR2 } & 0 & 0 & 0 & 1 & 5 & 0 & 0 & 0 & 1 & 1 & 1 & 1 & 0 & 0 & 0 & 0 & 0 & 0.66 & 3.1 & 9 & 0\end{array}$ $\begin{array}{llllllllllllllllllllll}\text { WPR3 } & 0 & 0 & 0 & 1 & 5 & 0 & 0 & 0 & 1 & 1 & 0 & 0 & 1 & 1 & 0 & 0 & 0 & 0.67 & 2.9 & 9 & 0\end{array}$ $\begin{array}{llllllllllllllllllllll}\text { WPR4 } & 0 & 0 & 0 & 1 & 5 & 0 & 0 & 1 & 0 & 0 & 1 & 0 & 1 & 1 & 0 & 1 & 0 & 0.86 & 3.7 & 9 & 0\end{array}$ $\begin{array}{llllllllllllllllllllll}\text { WPR5 } & 0 & 0 & 0 & 1 & 5 & 0 & 0 & 0 & 1 & 0 & 0 & 0 & 1 & 1 & 0 & 0 & 0 & 0.83 & 3.2 & 9 & 0\end{array}$ $\begin{array}{llllllllllllllllllllll}\text { WPR6 } & 0 & 0 & 0 & 1 & 5 & 0 & 0 & 0 & 1 & 0 & 1 & 0 & 1 & 1 & 0 & 0 & 0 & 0.73 & 3.2 & 7 & 0\end{array}$ $\begin{array}{llllllllllllllllllllll}\text { WPR7 } & 0 & 0 & 0 & 1 & 7 & 0 & 0 & 0 & 1 & 0 & 0 & 0 & 1 & 1 & 0 & 1 & 0 & 0.81 & 3.1 & 9 & 0\end{array}$ $\begin{array}{llllllllllllllllllllll}\text { WPR8 } & 0 & 1 & 0 & 0 & 5 & 0 & 0 & 0 & 1 & 0 & 0 & 0 & 1 & 1 & 0 & 1 & 0 & 0.65 & 2.3 & 9 & 0\end{array}$ $\begin{array}{llllllllllllllllllllll}\text { WPR9 } & 0 & 1 & 0 & 0 & 7 & 0 & 0 & 0 & 1 & 0 & 0 & 0 & 1 & 1 & 0 & 1 & 1 & 0.67 & 2.5 & 7 & 0\end{array}$ $\begin{array}{llllllllllllllllllllll}\text { WPU1 } & 0 & 0 & 0 & 1 & 5 & 0 & 0 & 0 & 1 & 1 & 1 & 1 & 1 & 1 & 0 & 1 & 0 & 0.73 & 3.4 & 8.6 & 0\end{array}$ $\begin{array}{llllllllllllllllllllll}\text { WPU2 } & 0 & 0 & 0 & 1 & 5.4 & 0 & 0 & 0 & 1 & 1 & 1 & 1 & 1 & 1 & 0 & 1 & 0 & 0.76 & 3.2 & 9 & 0\end{array}$ $\begin{array}{llllllllllllllllllllll}\text { WPU3 } & 0 & 0 & 0 & 1 & 5 & 0 & 0 & 0 & 1 & 1 & 1 & 1 & 1 & 1 & 1 & 1 & 1 & 0.70 & 3.2 & 8.5 & 0\end{array}$ $\begin{array}{llllllllllllllllllllll}\text { WPU4 } & 0 & 0 & 0 & 1 & 5 & 0 & 0 & 0 & 1 & 1 & 1 & 1 & 1 & 1 & 1 & 1 & 1 & 0.73 & 3.1 & 9 & 1\end{array}$ $\begin{array}{llllllllllllllllllllll}\text { WPU5 } & 0 & 0 & 0 & 1 & 5 & 0 & 0 & 0 & 0 & 1 & 1 & 1 & 1 & 1 & 1 & 1 & 1 & 0.77 & 2.9 & 9 & 1\end{array}$ $\begin{array}{llllllllllllllllllllll}\text { WPU6 } & 0 & 0 & 0 & 1 & 5 & 0 & 0 & 0 & 1 & 1 & 1 & 1 & 1 & 1 & 0 & 1 & 0 & 0.76 & 3.4 & 8.5 & 0\end{array}$

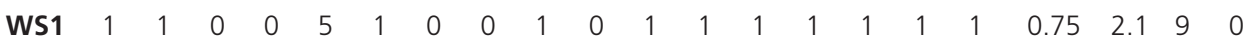

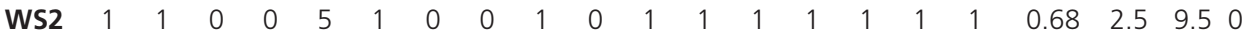

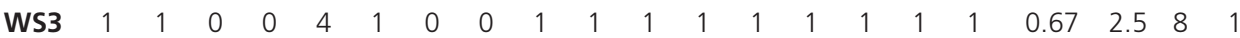

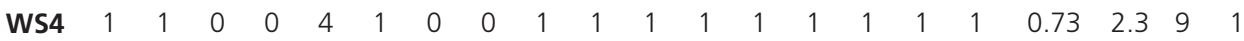
$\begin{array}{llllllllllllllllllllll}\text { WS5 } & 1 & 1 & 0 & 0 & 4 & 1 & 0 & 0 & 1 & 0 & 1 & 1 & 1 & 1 & 1 & 1 & 1 & 0.78 & 2.5 & 8.5 & 1\end{array}$ 
$\begin{array}{llllllllllllllllllllll}\text { OTU } & 41 & 42 & 43 & 44 & 45 & 46 & 47 & 48 & 49 & 50 & 51 & 52 & 53 & 54 & 55 & 56 & 57 & 58 & 59 & 60 & 61\end{array}$ $\begin{array}{llllllllllllllllllllll}\text { HB1 } & 0 & 1 & 0 & 1 & 0 & 1 & 1 & 0 & 1 & 0 & 1 & 0 & 0 & 1 & 1 & 0 & 01 & 0 & 1 & 0 & 1\end{array}$

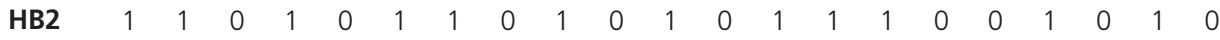
HB3 $\quad 0 \begin{array}{lllllllllllllllllllll}\text { HB } & 0 & 1 & 0 & 1 & 1 & 0 & 1 & 0 & 1 & 0 & 0 & 1 & 1 & 0 & 0 & 1 & 0 & 1 & 0\end{array}$ $\begin{array}{llllllllllllllllllllll}\text { HB4 } & 1 & 1 & 0 & 1 & 0 & 1 & 1 & 0 & 1 & 0 & 1 & 0 & 0 & 1 & 1 & 0 & 0 & 1 & 0 & 1 & 0\end{array}$

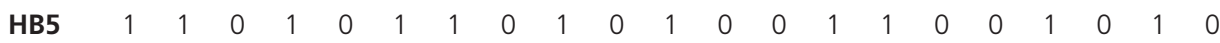
$\begin{array}{llllllllllllllllllllll}\text { HB6 } & 1 & 1 & 0 & 1 & 0 & 1 & 1 & 0 & 1 & 0 & 1 & 0 & 0 & 1 & 1 & 0 & 0 & 1 & 0 & 1 & 0\end{array}$

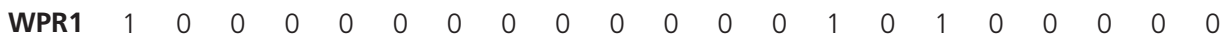

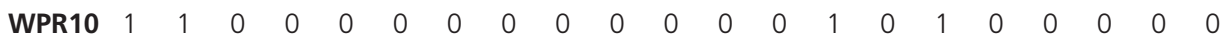

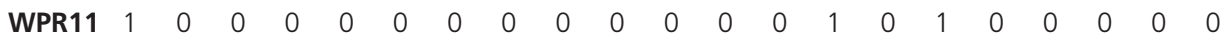
$\begin{array}{llllllllllllllllllllll}\text { WPR12 } & 1 & 0 & 0 & 0 & 0 & 0 & 0 & 0 & 0 & 0 & 0 & 0 & 0 & 1 & 0 & 1 & 0 & 0 & 0 & 0 & 0\end{array}$ $\begin{array}{llllllllllllllllllllll}\text { WPR13 } & 1 & 0 & 0 & 0 & 0 & 0 & 0 & 0 & 0 & 0 & 0 & 0 & 0 & 1 & 0 & 1 & 0 & 0 & 1 & 0 & 1\end{array}$

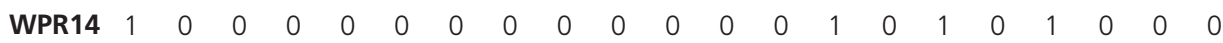

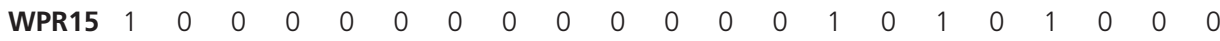
WPR16 $1100 \begin{array}{lllllllllllllllllll}\text { WP } & 0 & 0 & 0 & 0 & 0 & 0 & 0 & 0 & 0 & 0 & 1 & 0 & 1 & 0 & 0 & 0 & 0 & 0\end{array}$

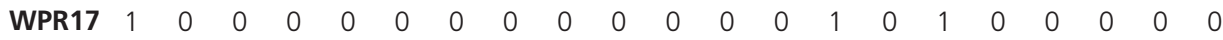
WPR18 $1100 \begin{array}{lllllllllllllllllll}\text { WP } & 0 & 0 & 0 & 0 & 0 & 0 & 0 & 0 & 0 & 0 & 1 & 0 & 1 & 0 & 1 & 0 & 0 & 0\end{array}$ $\begin{array}{llllllllllllllllllllll}\text { WPR2 } & 1 & 1 & 1 & 0 & 1 & 1 & 0 & 0 & 0 & 0 & 0 & 0 & 0 & 1 & 0 & 1 & 0 & 0 & 1 & 0 & 1\end{array}$ $\begin{array}{llllllllllllllllllllll}\text { WPR3 } & 1 & 1 & 1 & 0 & 1 & 0 & 0 & 0 & 0 & 0 & 0 & 0 & 0 & 1 & 0 & 1 & 0 & 0 & 1 & 0 & 1\end{array}$ $\begin{array}{llllllllllllllllllllll}\text { WPR4 } & 1 & 0 & 0 & 0 & 0 & 0 & 0 & 0 & 0 & 0 & 0 & 0 & 0 & 1 & 0 & 1 & 0 & 0 & 0 & 0 & 0\end{array}$

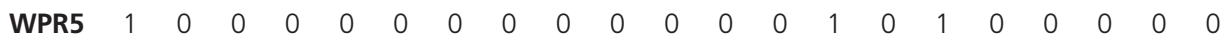

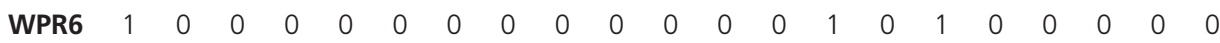
$\begin{array}{llllllllllllllllllllll}\text { WPR7 } & 1 & 0 & 0 & 0 & 0 & 0 & 0 & 0 & 0 & 0 & 0 & 0 & 0 & 1 & 0 & 1 & 0 & 0 & 0 & 0 & 0\end{array}$ $\begin{array}{llllllllllllllllllllll}\text { WPR8 } & 1 & 1 & 0 & 1 & 0 & 1 & 1 & 1 & 1 & 1 & 1 & 1 & 0 & 1 & 0 & 0 & 1 & 0 & 0 & 1 & 0\end{array}$ $\begin{array}{llllllllllllllllllllll}\text { WPR9 } & 1 & 1 & 0 & 1 & 0 & 1 & 1 & 1 & 1 & 1 & 1 & 1 & 0 & 1 & 0 & 0 & 1 & 0 & 0 & 1 & 0\end{array}$ $\begin{array}{llllllllllllllllllllll}\text { WPU1 } & 1 & 1 & 1 & 0 & 1 & 1 & 1 & 0 & 1 & 0 & 1 & 0 & 0 & 1 & 0 & 1 & 1 & 0 & 1 & 0 & 1\end{array}$ $\begin{array}{llllllllllllllllllllll}\text { WPU2 } & 1 & 1 & 1 & 0 & 1 & 1 & 1 & 0 & 1 & 0 & 1 & 0 & 0 & 1 & 0 & 1 & 1 & 0 & 1 & 0 & 1\end{array}$ $\begin{array}{llllllllllllllllllllll}\text { WPU3 } & 1 & 1 & 1 & 0 & 1 & 1 & 0 & 0 & 0 & 0 & 0 & 0 & 0 & 1 & 0 & 0 & 1 & 0 & 1 & 0 & 1\end{array}$ $\begin{array}{llllllllllllllllllllll}\text { WPU4 } & 0 & 1 & 1 & 0 & 1 & 1 & 1 & 0 & 1 & 0 & 1 & 0 & 1 & 0 & 0 & 1 & 0 & 0 & 1 & 0 & 1\end{array}$ $\begin{array}{llllllllllllllllllllll}\text { WPU5 } & 0 & 1 & 1 & 0 & 1 & 1 & 1 & 0 & 1 & 0 & 1 & 0 & 0 & 1 & 0 & 1 & 0 & 0 & 1 & 0 & 1\end{array}$ $\begin{array}{llllllllllllllllllllll}\text { WPU6 } & 1 & 1 & 1 & 0 & 1 & 1 & 1 & 0 & 1 & 0 & 1 & 0 & 1 & 1 & 0 & 1 & 0 & 0 & 1 & 0 & 1\end{array}$

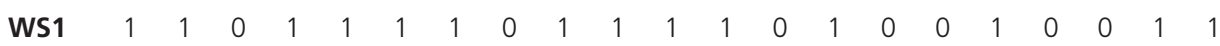
$\begin{array}{llllllllllllllllllllll}\text { WS2 } & 1 & 1 & 0 & 1 & 1 & 1 & 1 & 0 & 1 & 1 & 1 & 1 & 0 & 1 & 0 & 0 & 1 & 0 & 0 & 1 & 1\end{array}$ WS3 $\quad 0 \begin{array}{lllllllllllllllllllll} & 0 & 0 & 1 & 1 & 1 & 1 & 0 & 1 & 1 & 1 & 1 & 1 & 0 & 0 & 0 & 1 & 0 & 0 & 1 & 1\end{array}$ WS4 $\quad 0 \begin{array}{lllllllllllllllllllll} & 0 & 1 & 1 & 1 & 1 & 1 & 1 & 1 & 1 & 1 & 1 & 1 & 0 & 0 & 0 & 1 & 0 & 1 & 0 & 1\end{array}$

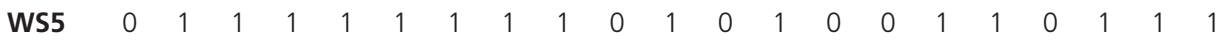


OTU $\begin{array}{lllllllllllllllllllll}62 & 63 & 64 & 65 & 66 & 67 & 68 & 69 & 70 & 71 & 72 & 73 & 74 & 75 & 76 & 77 & 78 & 79 & 80 & 81 & 82\end{array}$

HB1

$\begin{array}{llllllllllll}1 & 0 & 1 & 0 & 1 & 0 & 7 & 0 & 1 & 0 & 1 & 0\end{array}$

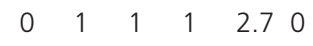

$\mathrm{HB} 2$

HB3

HB4

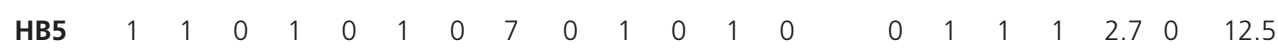

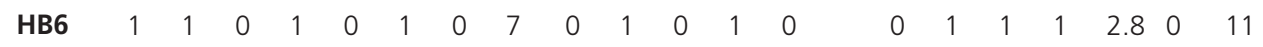

$\begin{array}{llllllllllllllllllllll}\text { WPR1 } & 0 & 0 & 0 & 0 & 0 & 0 & 0 & 7 & 0 & 0 & 1 & 1 & 1 & 1 & 0 & 1 & 1 & 1 & 2.1 & 0 & 10.5\end{array}$

$\begin{array}{llllllllllllllllllllll}\text { WPR10 } & 0 & 0 & 0 & 0 & 0 & 0 & 0 & 9 & 1 & 0 & 1 & 1 & 1 & 1 & 0 & 0 & 0 & 1 & 2.3 & 0 & 11.5\end{array}$

$\begin{array}{llllllllllllllllllllll}\text { WPR11 } & 0 & 0 & 0 & 0 & 0 & 0 & 0 & 7 & 0 & 0 & 1 & 0 & 1 & 1 & 0 & 1 & 1 & 1 & 2.0 & 0 & 11\end{array}$

$\begin{array}{llllllllllllllllllllll}\text { WPR12 } & 0 & 0 & 0 & 0 & 0 & 0 & 0 & 7 & 0 & 0 & 1 & 1 & 1 & 1 & 0 & 1 & 1 & 1 & 2.2 & 0 & 11\end{array}$

$\begin{array}{llllllllllllllllllllll}\text { WPR13 } & 0 & 0 & 0 & 0 & 0 & 0 & 0 & 7 & 0 & 0 & 1 & 1 & 0 & 0 & 1 & 1 & 1 & 1 & 2.2 & 0 & 6.5\end{array}$

$\begin{array}{llllllllllllllllllllll}\text { WPR14 } & 0 & 0 & 0 & 0 & 0 & 0 & 0 & 7 & 0 & 0 & 1 & 1 & 1 & 0 & 1 & 1 & 1 & 1 & 2.1 & 0 & 8.5\end{array}$

$\begin{array}{llllllllllllllllllllll}\text { WPR15 } & 0 & 0 & 0 & 0 & 0 & 0 & 0 & 8 & 0 & 0 & 1 & 1 & 1 & 0 & 0 & 1 & 1 & 1 & 2.1 & 0 & 10\end{array}$

$\begin{array}{lllllllllllllllllll}\text { WPR16 } & 0 & 0 & 0 & 0 & 0 & 0 & 0 & 0 & 1 & 1 & 0 & 0 & 1 & 1 & 0 & 2.3 & 0 & 10\end{array}$

$\begin{array}{llllllllllllllllllllll}\text { WPR17 } & 0 & 0 & 0 & 0 & 0 & 0 & 0 & 7 & 0 & 0 & 1 & 1 & 1 & 0 & 1 & 1 & 1 & 1 & 2.1 & 0 & 9.5\end{array}$

$\begin{array}{llllllllllllllllllllll}\text { WPR18 } & 0 & 0 & 0 & 0 & 0 & 0 & 0 & & 0 & 0 & 1 & 1 & 1 & 0 & 1 & 1 & 1 & 1 & 2.1 & 0 & 8.5\end{array}$

$\begin{array}{llllllllllllllllllllll}\text { WPR2 } & 1 & 0 & 0 & 0 & 0 & 0 & 0 & 7 & 0 & 0 & 1 & 1 & 1 & 1 & 0 & 1 & 1 & 1 & 2.0 & 0 & 11\end{array}$

$\begin{array}{llllllllllllllllllllll}\text { WPR3 } & 0 & 0 & 0 & 0 & 0 & 0 & 0 & 7 & 0 & 0 & 1 & 1 & 1 & 1 & 0 & 1 & 1 & 1 & 2.2 & 0 & 9\end{array}$

$\begin{array}{llllllllllllllllllllll}\text { WPR4 } & 0 & 0 & 0 & 0 & 0 & 0 & 0 & 7 & 1 & 0 & 1 & 1 & 1 & 1 & 0 & 0 & 1 & 1 & 2.5 & 0 & 5\end{array}$

$\begin{array}{llllllllllllllllllllll}\text { WPR5 } & 0 & 0 & 0 & 0 & 0 & 0 & 0 & 7 & 1 & 0 & 1 & 1 & 1 & 1 & 0 & 0 & 1 & 1 & 2.3 & 0 & 10.5\end{array}$

$\begin{array}{llllllllllllllllllllll}\text { WPR6 } & 0 & 0 & 0 & 0 & 0 & 0 & 0 & 7 & 0 & 0 & 1 & 1 & 1 & 1 & 0 & 1 & 1 & 1 & 2.2 & 0 & 10\end{array}$

$\begin{array}{llllllllllllllllllllll}\text { WPR7 } & 0 & 0 & 0 & 0 & 0 & 0 & 0 & 7 & 0 & 0 & 1 & 1 & 1 & 1 & 0 & 1 & 1 & 0 & 2.1 & 1 & 6.5\end{array}$

$\begin{array}{llllllllllllllllllllll}\text { WPR8 } & 1 & 1 & 1 & 1 & 1 & 1 & 1 & 9 & 1 & 0 & 1 & 0 & 1 & 1 & 0 & 1 & 1 & 1 & 1.8 & 1 & 11\end{array}$

$\begin{array}{llllllllllllllllllllll}\text { WPR9 } & 1 & 1 & 1 & 1 & 1 & 1 & 1 & 7 & 1 & 0 & 1 & 0 & 1 & 1 & 0 & 1 & 1 & 1 & 2.1 & 1 & 8.5\end{array}$

$\begin{array}{llllllllllllllllllllll}\text { WPU1 } & 1 & 1 & 0 & 1 & 0 & 0 & 0 & 8 & 0 & 0 & 1 & 1 & 1 & 0 & 1 & 1 & 1 & 1 & 2.8 & 0 & 13\end{array}$

$\begin{array}{llllllllllllllllllllll}\text { WPU2 } & 1 & 0 & 0 & 0 & 0 & 0 & 0 & & 0 & 1 & 0 & 1 & 1 & 0 & 1 & 1 & 1 & 1 & 2.6 & 0 & 11\end{array}$

$\begin{array}{lllllllllllllllllllll}\text { WPU3 } & 1 & 0 & 0 & 0 & 0 & 0 & 0 & 9 & 0 & 0 & 1 & 1 & 1 & 0 & 1 & 1 & 1 & 1 & 2.6 & 0\end{array}$

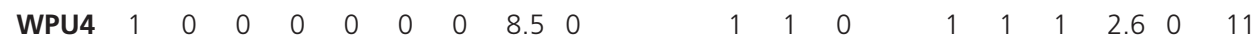

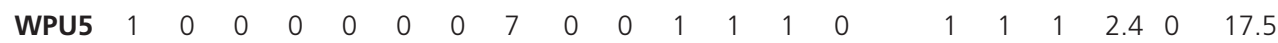

$\begin{array}{llllllllllllllllll}\text { WPU6 } & 1 & 0 & 0 & 0 & 0 & 0 & 0 & 7.5 & 1 & 1 & 0 & 1 & 1 & 1 & 2.6 & 0 & 15\end{array}$

$\begin{array}{llllllllllllllllllllll}\text { WS1 } & 1 & 1 & 0 & 1 & 1 & 1 & 1 & 9 & 0 & 0 & 1 & 0 & 1 & 0 & 0 & 0 & 1 & 0 & 1.9 & 0 & 12\end{array}$

$\begin{array}{llllllllllllllllllllll}\text { WS2 } & 1 & 1 & 0 & 1 & 1 & 1 & 1 & 9 & 0 & 0 & 1 & 0 & 1 & 0 & 1 & 0 & 1 & 0 & 2.1 & 0 & 11\end{array}$

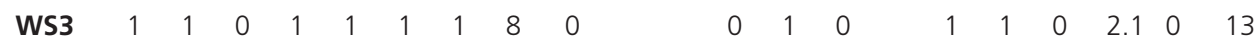

$\begin{array}{llllllllllllllllllllll}\text { WS4 } & 1 & 1 & 0 & 1 & 1 & 1 & 1 & 8 & 0 & 0 & 1 & 0 & 1 & 0 & 0 & 1 & 1 & 0 & 2.0 & 0 & 14\end{array}$

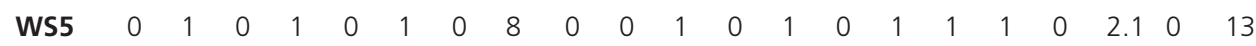

